\title{
Professional Qualities and Interpersonal Skills of Grade 11 Teachers of Sangali National High School
}

\author{
Rene Nathaniel M. Acacio* \\ a reneoicaca@gmail.com
}

\begin{abstract}
The study will determine the level of Professional Qualities and Interpersonal skills of Grade 11 teachers of Sangali National High School, Zamboanga City. And to determine the relationship between Professional Qualities and Interpersonal skills and student's motivation.

The study revealed that The Professional Qualities of Grade 11 Teachers of Sangali National High School has no significant relationship with the student's motivations. Similarly, the interpersonal skills of grade 11 teachers of Sangali National High School have no significant relationship with the student's motivation.

Grade 11 Students of Sangali National High School were high motivated. Based from the findings, the Professional Qualities of Grade 10 Grade 11 teachers of Sangali National High School were excellent in terms of Diversity of Learners, Assessment and Reporting and Curriculum Planning. They were good in learning Environment, professional growth and Professional Development.

Grade 11 teachers of Sangali National High School, their level of Interpersonal skills was Excellent in terms of Communication Skills, Listening Skills, Emotional Intelligence and working with groups/teams.
\end{abstract}

Keywords: Professional Qualities, Interpersonal Skills, Grade 11 teachers, Student's Motivation, Sangali National High School,

\section{Introduction}

Teachers play a significant role in empowering students. As a result, they should possess qualities and skills that will enable them to relate with the students and foster the development of social and technical skills among the students.

Excellent teachers serve as role models, influence career advice and enable students to reach their potential. Some of the necessary qualities are 
inherent, others can be acquired Azer (2005).

As a matter of fact, Cohen and its relationship to student's learning has traditionally utilized education product models. Teachers figure as a key connection between policy and practice, their opportunities to learn about and from policy are a crucial influence both on their practice and at least indirectly on student achievement.

Notably, Loss (2007) highlighted that teachers need clear communication for the good understanding of students and avoiding the problems, for students while learning from their lecture. It is also needed by the teachers to understand first himself before teaching to students.

Admittedly, Sng (2012) proffered that teachers have to teach the students have different thinking approaches to teach in accordance with the ability and capability of the students, a teacher needs to adopt such skills of communication which motivate the students toward their learning process.

Moreover, Silver (2017) presented some effective communication skills that are important for a teacher in transmitting of education, classroom management and interventions with students in the class.

Whereas, Azer (2005) student that good tecahers enthusiastic, friendly, easy-going, able to develop support with learners, committed to the growth of their students, approachable, interested in learners as people, and always conscious of their status as role models.

For this reason, Meyers et al (2009) asserted that teacher empathy is the degree to which an instructor works to deeply understand students personal and social situations, to feel care and concern in response to students positive and negative emotions, and to respond compassionately without closing the forms on student learning. Teacher empathy is communicated to students through course policies as well as the instruction's behavior toward students.

Thus, the study is conducted to examine teachers' professional qualities and interpersonal skills for the crafting of a professional and interpersonal development program for teachers.

\section{Statement of the Problem}

This study seeks to evaluate the level of professional qualities and interpersonal skills of Grade 11 Teachers of Sangali National High School Specifically, the study aims to establish the substantive explanation of the problem statements that follows:

This study seeks to determine the level of professional qualities and interpersonal skills among Grade 11 Teachers of Sangali National High School.

Specifically, the study intends to answer the following questions:

1. What is the level of professional qualities among Grade 11 teachers of Sangali National High School in terms of:

1.1 content knowledge and pedagogy

1.2 learning environment

1.3 diversity of learners

1.4 curriculum and planning

1.5 assessment and reporting

1.6 professional growth and professional development 
2. What is the level of interpersonal skills among Grade 11 teachers of Sangali National High School in terms of:
2.1 Communication skill
2.2 Listening skills
2.3 Emotional Intelligence
2.4 Working in groups/teams

3. What is the level of students' motivation?

4. Is there a significant relationship in the level of professional qualities and student's motivation?

5. Is there a significant relationship in the level of interpersonal skills and student's motivation?

6. Is there a significant difference in the teacher's professional qualities when respondents are grouped according to age, length of service? 7. Is there a significant difference in the teacher's interpersonal skills when respondents are grouped according to age, length of service?

\section{RESULT AND DISCUSSION}

Problem 1: What is the level of Professional Qualities among Grade 11 Teachers of Sangali National High School.

Table 1:

level of Professional Qualities among Grade 11 Teachers of Sangali National High Professional Qualities Mean Interpretation 1

Content Knowledge and

3.37

Good Pedagogy

\begin{tabular}{clcc}
\hline $\mathbf{2}$ & Learning Environment & 3.40 & Excellent \\
\hline $\mathbf{3}$ & Diversity of Learners & 3.49 & Excellent \\
\hline $\mathbf{4}$ & Curriculum and Planning & 3.37 & Good \\
$\mathbf{5}$ & Assessment and reporting & 3.49 & Excellent \\
\hline $\mathbf{6}$ & $\begin{array}{l}\text { Professional growth and } \\
\text { professional development }\end{array}$ & 3.34 & Good \\
\hline & & 3.41 & Excellent \\
\hline
\end{tabular}

Legend: 3.40-4.00 Excellent, 2.60-3.39 Good, 1.80-2.59 Fair 1.00- 1.79 Low

Table 1 shows that the level of professional qualities among grade 11 teachers at Sangali National High School was excellent, with an overall mean of 3.41. The professional qualities of grade 11 teachers in terms of diversity of learners were excellent, with a mean of 3.49. This implies that teachers really considered the differences of the students they made belong to the group, no matter what race, culture, gender, or the like they belong to. And as for the assessment and reporting teachers, they were also excellent, with a mean of 3.49. 
On the other hand, grade 11 teachers at Sangali National High School were good in content knowledge and pedagogy with a mean of 3.37. This means that teachers have the ability to evaluate the context in which they teach and act accordingly, and they also have the ability to create and facilitate an effective teaching learning process. As to curriculum and planning, they obtained a mean of 3.37. This means that grade 11 teachers at Sangali National High School have the ability to apply theoretical principles in the implementation of a particular curriculum model. The teachers should be aware of the textbooks that they will use, the curriculum, rules, as well as the laws of the education system as a unit. Furthermore, ideal modern teachers should critically approach the curriculum. A critical approach will ensure that the teachers can effectively plan the content that they will teach. Also, it will ensure that teachers meet the needs of the curriculum. Moreover, in terms of professional growth and professional development, they were good, with a mean of 3.34.

\section{Problem 2: What is the level of Interpersonal Skills among Grade 11 Teachers of Sangali National High School.}

Table 2:

level of Interpersonal Skills among Grade 11 Teachers of Sangali National High

\begin{tabular}{llcc}
\hline Professional Qualities & Mean & Interpretation \\
\hline $\mathbf{1}$ & Communication Skills & 4.46 & Excellent \\
\hline $\mathbf{2}$ & Listening Skills & 3.51 & Excellent \\
\hline $\mathbf{3}$ & Emotional Intelligence & 3.51 & Excellent \\
\hline $\mathbf{4}$ & Working in groups/teams & 3.57 & Excellent \\
\hline Overall Mean & 3.41 & Excellent \\
\hline
\end{tabular}

Legend: 3.40-4.00 Excellent, 2.60-3.39 Good, 1.80-2.59 Fair 1.00- 1.79 Low

As shown in table 2, the Sangali National High School Grade 11 teachers were excellent in their interpersonal skills, with an overall mean of 4.41. In terms of communication skills, the grade 11 teachers of Sangali National High School were excellent. This implies that teachers were excellent in transmitting education, classroom management, and interaction with students in the class. To teach in accordance with the ability and capability of the students, a teacher needs to adopt communication skills that motivate the students toward their learning process. In addition, the listening skills of Grade 11 teachers at Sangali National High School were also excellent, with a mean of 3.51. This shows that the teachers are able to listen to the students. Besides, there will be effective communication between the teachers and students. The reason for this assertion is that when the teachers listen to the students, they are actively involved in communication with them. Communication is an important factor since it enhances the effectiveness of the interaction between the student and the teacher. As to the teachers' 
emotional intelligence, they were also excellent, with a mean of 3.51. This implies that the teachers were excellent at managing their own emotions. Hence, they can not only organize and manage the classroom environment, but they can also manage the behaviors of the students to increase the positive academic outcomes. Furthermore, in terms of working in groups or teams, grade 11 teachers at Sangali National High School were also excellent with a mean of 3.57. This means that they can work collaboratively and cooperate with each other to perform the job and produce a good output.

Problem 3. What is the level of Student's Motivation?

Table 3:

Level of Students' Motivation

\begin{tabular}{|c|c|c|}
\hline Student's Motivation & Mean & Interpretation \\
\hline tries different ways to solve study problems. & 3.49 & High Motivated \\
\hline studies hard as much as possible. & 3.51 & High Motivated \\
\hline sets realistic and challenging study goals. & 3.52 & High Motivated \\
\hline values achievements in studies. & 3.49 & High Motivated \\
\hline encourages others to learn. & 3.55 & High Motivated \\
\hline shows interest in learning. & 3.41 & High Motivated \\
\hline participates in class discussions. & 3.53 & High Motivated \\
\hline pays attention in the class. & 3.41 & High Motivated \\
\hline asks questions for better understanding. & 3.55 & High Motivated \\
\hline takes studies as his/her personal responsibility. & 3.55 & High Motivated \\
\hline strives harder to get high grades. & 3.53 & High Motivated \\
\hline enjoys studying. & 3.46 & High Motivated \\
\hline $\begin{array}{l}\text { loves to get honor and praise from families and } \\
\text { others for passing. }\end{array}$ & 3.46 & High Motivated \\
\hline likes to solve problems in studies. & 3.48 & High Motivated \\
\hline looks forward to the next class meetings. & 3.55 & High Motivated \\
\hline Overall Mean & 3.50 & High Motivated \\
\hline
\end{tabular}

Legend: 3.40- 4.00 Highly Motivated, 2.60-3.39 Motivated, 1.80-2.59 Less

Motivated, 1.00- 1.79 Not Motivated

It is shown in Table 3 that the students were highly motivated, with a mean of 3.50. Students were highly motivated in trying different ways to solve study problems (3.49); studying as much as possible (3.51); setting realistic and challenging study goals (3.52); valuing academic achievement (3.55); showing interest in learning (3.41); participating in class discussion (3.43); paying attention in class (3.41); asking questions for better understanding (3.55); taking studies as his/her personal responsibility (3.55); striving for a high grade (3.55);

Problem 4 Is there a significant relationship in the level of professional qualities and student's motivation? 
Table 4:

Significant Relationship in the level of professional Qualities and Student's Motivation

\begin{tabular}{cccccc}
$\mathbf{x}$ & $\mathbf{y}$ & $\mathbf{r}$-value & $\mathbf{p}$-value & Decision & interpretation \\
\hline $\begin{array}{c}\text { Professional } \\
\text { Qualities }\end{array}$ & $\begin{array}{c}\text { Students } \\
\text { Motivation }\end{array}$ & -0.343 & 0.452 & $\begin{array}{c}\text { Not } \\
\text { significant }\end{array}$ & $\begin{array}{c}\text { Negative Low } \\
\text { correlation }\end{array}$ \\
\hline Alpha 0.05 & & & & &
\end{tabular}

Table 4 reveals that the result of spearman rank rho was a negative low correlation with -0.343 between the professional qualities and the students' motivation, which indicates that there is no significant relationship between the professional qualities and the students' motivation ( $p=0.452)$.

Problem 5. Is there a significant relationship in the level of interpersonal skills and student's motivation?

Table 5:

Significant Relationship in the level of Interpersonal Skills and Student's Motivation

\begin{tabular}{cccccc}
\hline $\mathbf{x}$ & $\mathbf{Y}$ & $\mathbf{r}$-value & $\begin{array}{c}\mathbf{p}- \\
\text { value }\end{array}$ & Decision & interpretation \\
\hline $\begin{array}{c}\text { Interpersonal } \\
\text { Skills }\end{array}$ & $\begin{array}{c}\text { Students } \\
\text { Motivation }\end{array}$ & 0.275 & 0.55 & $\begin{array}{c}\text { Not } \\
\text { significant }\end{array}$ & $\begin{array}{c}\text { High } \\
\text { correlation }\end{array}$ \\
\hline
\end{tabular}

Alpha 0.05

Table 5 reveals that the result of spearman rank rho was a high correlation with a value of 0.55 between the interpersonal skills and the students' motivation, which indicates that there is no significant relationship between the interpersonal skills and the students' motivation ( $p=0.275)$.

Problem 6 . Is there a significant difference in the teacher's professional qualities when respondents are grouped according to age, length of service?

Table 6:

ANOVA Result of Significant Difference in teachers' professional qualities when respondents grouped according to age

\begin{tabular}{ccccccc}
\hline & $\begin{array}{c}\text { Sum of } \\
\text { Squares }\end{array}$ & Df & $\begin{array}{c}\text { Mean } \\
\text { Square }\end{array}$ & F & Sig. & Interpretation \\
\hline $\begin{array}{c}\text { Between } \\
\text { Groups }\end{array}$ & .023 & 3 & .008 & & & Not \\
$\begin{array}{c}\text { Within Groups } \\
\text { Total }\end{array}$ & .070 & 3 & .023 & .331 & .806 & Significant \\
\hline Alpha 0.05 & .093 & 6 & & & & \\
\hline
\end{tabular}


Table 6 shows that there is no significant difference in the professional qualities of grade 11 teachers in Sangali National High School when data are analyzed by age, with an $\mathrm{f}$-value of 0.331 and a $\mathrm{p}$-value of 0.806 higher than alpha 0.05 , implying that the professional skills of grade 11 teachers in Sangali National High School did not differ by age.

Table 7:

ANOVA Result of Significant Difference in teachers' professional qualities when respondents grouped according to Length of Service

\begin{tabular}{ccccccc}
\hline & $\begin{array}{c}\text { Sum of } \\
\text { Squares }\end{array}$ & Df & $\begin{array}{c}\text { Mean } \\
\text { Square }\end{array}$ & F & Sig. & Interpretation \\
\hline Between & .011 & 3 & .006 & & & Not \\
$\quad$ Groups & .081 & 4 & .020 & .278 & .771 & Significant \\
$\begin{array}{c}\text { Within Groups } \\
\text { Total }\end{array}$ & .092 & 6 & & & & \\
\hline
\end{tabular}

Alpha 0.05

Table 7 shows that when data are analyzed according to length of service, the f-value of 0.278 and $p$-value of 0.771 , both greater than alpha 0.05 , indicate that there is no significant difference in the professional qualities of grade 11 teachers in Sangali National High School, implying that the professional skills of grade 11 teachers in Sangali National High School did not differ.

Problem 7. Is there a significant difference in the teacher's interpersonal skills when respondents are grouped according to age, length of service?

Table 8:

ANOVA Result of Significant Difference in teachers' Interpersonal Skills when respondents grouped according to age

\begin{tabular}{ccccccc}
\hline & $\begin{array}{c}\text { Sum of } \\
\text { Squares }\end{array}$ & Df & $\begin{array}{c}\text { Mean } \\
\text { Square }\end{array}$ & F & Sig. & Interpretation \\
\hline Between & .016 & 3 & .005 & & & Not \\
Groups & .013 & 3 & .004 & 1.212 & .439 & Significant \\
$\begin{array}{c}\text { Within Groups } \\
\text { Total }\end{array}$ & .029 & 6 & & & & \\
\hline
\end{tabular}

Table 8 shows that the $f$-value of 0.318 and a $p$-value of 0.058 higher than alpha 0.05 indicates there is no significant difference in the interpersonal skills of grade 11 teachers in Sangali National High School when data is analyzed according to age. This implies that in terms of ages, the professional skills of grade 11 teachers in Sangali National High School did not differ.

Table 9: 


\begin{tabular}{ccccccc}
\multicolumn{6}{c}{$\begin{array}{c}\text { ANOVA Result of Significant Difference in teachers' Interpersonal Skills when } \\
\text { respondents grouped according to Length of Service }\end{array}$} \\
$\begin{array}{c}\text { Sum of } \\
\text { Squares }\end{array}$ & Df $\begin{array}{c}\text { Mean } \\
\text { Square }\end{array}$ & F & Sig. & Interpretation \\
\hline Between & .022 & 3 & .011 & & & Not \\
$\begin{array}{c}\text { Groups } \\
\text { Sithin Groups }\end{array}$ & .007 & 4 & .002 & 6.312 & .058 & Significant \\
Total & .029 & 6 & & & & \\
\hline
\end{tabular}

Table 9 shows that when data are analyzed according to length of service, the fvalue of 1.212 and $p$-value of 0.439 are greater than alpha 0.05 , indicating that there is no significant difference in the interpersonal skills of grade 11 teachers in Sangali National High School, implying that the professional skills of grade 11 teachers in Sangali National High School did not differ.

Conclusions

1. The professional qualities of grade 11 teachers at Sangali National High School have no significant relationship with the student's motivations. Similarly, the interpersonal skills of grade 11 teachers at Sangali National High School have no significant relationship with the student's motivation.

2. Grade 11 students at Sangali National High School were highly motivated.

3. Based on the findings, the professional qualities of grade 10 and grade 11 teachers at Sangali National High School were excellent in terms of diversity of learners, assessment and reporting, and curriculum planning. They were good at learning environments, professional growth, and professional development.

4. Grade 11 teachers of Sangali National High School had excellent interpersonal skills in terms of communication skills, listening skills, emotional intelligence, and working with groups/teams.

\section{Recommendations}

1. Administrators should encourage and motivate teachers to pursue higher degrees for personal growth and professional development.

2. designed programs for teachers to encourage them to constantly improve their professional qualities and interpersonal skills 


\section{REFERENCES}

Bilbao, Purita P. (2009). The Teaching Profession, Lorimar Publishing Co., Inc., Quezon City, Manila.

Brotheridge, 2006C.M. Brotheridge The role of emotional intelligence and other individual difference variables in predicting emotional labor relative to situational demands

Psicothema (18 Suplemento) (2006), pp. S139-S144

Claessens, B. J. C., van Eerde, W., \& Rutte, C. G. (2007). A review of the time manage-ment literature. Personnel Review, 36, 255-276.

doi:10.1108/00483480710726136

Ehindero, OJ, Ajibade YA (2000). What our student say about how we teach. Ife J. Educ. Studies. 7(1), 1-9.

Felton, S \& Sims, M. (2009). Organizing Your Day: Time Management Techniques That Will Work for You. Revell Publishing House.

Jackson, D. (2013). Bussines graduate performance in oral communication skills snd strategiesc for improvement. The International Journal of Management Education, nr. 12 (1), pp. 22-34. jps.hyperion.ro/wpcontent/uploads/2021/03/RJPS_nr_91_2021_A8_Groza -Croitoru.pdf

Maes, J. D., Weldy, T. G., \&lcenogle, M. L. (1997). A managerial perspective: Oral communication competency is most important for business students in the workplace. Journal of Business Communication, 34(1), 67-80.

Mayer et al., 199 J.D. Mayer, D.R. Caruso, P. SaloveyEmotional intelligence meets traditional standards for an intellige Intelligence, 27 (4) (1999), pp. 267-298

Peck, M. S. (2003). The road less traveled, 25th anniversary edition: A new psychology of love, traditional values and spiritual growth. New York, NY: Simon \& Schuster (PDF) the qualities of a good teacher: How can they be acquired and sustained?

ResearchGate. (n.d.). Retrieved September 13, 2021, from https://www.researchgate.net/publication/8048719_The_qualities_of_a_g ood_teacher_How_can_they_be_acquired_and_sustained. 